\title{
A factor analytic structure of the conceptions of mathematics scale among pre-service mathematics teachers in South-West Nigeria
}

\author{
Adeneye Olarewaju Awofala ${ }^{1 *}$, Abisola Olusola Lawani ${ }^{2}$, Chidinma O. Oraegbunam ${ }^{1}$ \\ ${ }^{1}$ Department of Science and Technology Education, Faculty of Education, University of Lagos, Nigeria \\ ${ }^{2}$ Department of Mathematics, College of Science and Information Technology, Tai Solarin University of \\ Education, Nigeria
}

*Corresponding author: aawofala@unilag.edu.ng

\begin{tabular}{l} 
ARTICLE INFO \\
\hline Article history: \\
Received: 11 December 2019 \\
Revised: 18 Februay 2020 \\
Accepted: 20 February 2020 \\
Published online: 28 February \\
2020 \\
Published regularly: February \\
2020
\end{tabular}

Keywords:

Psychometric properties, conceptions of mathematics scale, pre-service teachers, factor analytic structure

\section{ABSTRACT}

An exploration of factor analytic structure of the conceptions of mathematics scale among pre-service mathematics teachers in SouthWest Nigeria was conducted as evidence suggests paucity of research on psychometric properties of the conceptions of mathematics scale in Nigeria.This article through instrumentation research methodology reports the reliability and validity of the Conceptions of Mathematics Scale based on the responses of 228 pre-service mathematics teachers from five public universities in South-West Nigeria. The reliability assessed as internal consistency produced a Cronbach alpha of .88. A principal components exploration with varimax gyration established the validity of the scale as two-component archetypal accounting for $48.9 \%$ of the total variance. The dimensions were taken as Patchy Formations and Unified Formations of mathematics, as explicated in the original and other replicating studies. The factor solution could be compared to that recounted in the previous studies; hence the outcome showed the need to adopt the scale in the Nigerian context, as the pedagogy implemented during the teaching and learning of mathematics can influence students' conceptions of mathematics. Thus, teaching mathematics with rulesbased and algorithm-dependent teacher-centered pedagogies might result into rote memorization thereby leading to patchy formations while teaching mathematics as a meaningful subject full of applications to the real life could engender conceptual understanding leading to unified formations. The implication of this study is that students with patchy formation are connected with surface approaches to learning while those with unified formation of mathematics are connected with deep approaches to learning and engaging mathematics.

(C) 2020 Universitas Muhammadiyah Surakarta

\section{Introduction}

In general, school mathematics primarily deals with rules, formulas, and algorithms apply to solve problems. In essence, this thought of school mathematics is a common perception held about mathematics and has influenced both the instruction and erudition

To cite this article:

Awofala, A. O., Lawani, A. O., \& Oraegbunam, C. O. (2020). A factor analytic structure of the conceptions of mathematics scale among pre-service mathematics teachers in south-west Nigeria. JRAMathEdu (Journal of Research and Advances in Mathematics Education), 5(1), 94-104. doi:https://doi.org/10.23917/jramathedu.v5i1.9491 
of mathematics in schools. It is only in order that learners have so conceptualized the mathematics owing to the influence of how teachers have presented and taught it to them, which in turn influences their learning. Howbeit, educational reforms around the world have become amenable to learner-centered approaches to classroom mathematics instructions. The reforms urge teachers to teach and build deep conceptual understanding of mathematics concepts in order to develop strong mathematical skills (that include the ability to inquire, conceptualize, quantitatively reason and engage in problem-solving) rather than developing mental calculation and computational skills alone (Erdem \& Gürbüz, 2015; NERDC, 2013). In particular, the innovative 9-year basic education mathematics curriculum in Nigeria (Awofala, 2012) lays more emphasis on the use of contemporary pedagogies such as active learning, cooperative and collaborative learning and the use of authentic and real-world problem-based tasks. With this, pupils can engage mathematics learning through a series of multidimensional activities such as reading, writing, talking, listening and reflection which afford them the ample opportunity to elucidate, query, apply and associate new knowledge (Awofala, Ola-Oluwa, \& Fatade, 2012; Awofala, 2012). Despite the adoption of this curriculum, traditional pedagogies continue to persist in Nigerian schools (Awofala \& Awolola, 2011) and mathematics is taught without personalizing the problem context (Akinsola \& Awofala, 2008) thereby making the learning of mathematics difficult for students. In essence, the issue does not so much lie on persuading teachers to adopt reform-based pedagogies as it is on understanding how teachers conceive the whole idea of mathematics to be.

The Conceptions of Mathematics Scale (CMS) is an inventory produced in Australia through Crawford, Gordon, Nicholas and Prosser (1998a, 1998b) to assess beginning university learners' conceptions or formations of mathematics. Their mathematics conceptual scheme was twofold: fragmented conceptions or patchy formations and cohesive conceptions or unified formations of mathematics (Crawford, Gordon, Nicholas, \& Prosser, 1994). Accordingly, the scale consisted of both the patchy formations' subscale and the unified formations' subscale. Students who hold patchy formations see mathematics subject matter as comprising figures, guidelines and formulas, while students with unified formations describe mathematics as a multifarious, rational system that provides insight for comprehending the universe. It follows that a person with patchy formations of mathematics would focus on constituent parts rather than on the whole, and another that views mathematics cohesively would focus on the whole rather than on the parts.

In relation to how students learn mathematics, Crawford et al. (1998a) found that patchy formations were responsible for students' surface approach to learning, in which the students learning concentrates simply reproducing knowledge. While unified formations of mathematics correlated with a profound learning methodology, wherein students develop a general and individual viewpoint to learning in a bid to build personal meaning and understanding and consolidate knowledge. It is proposed that how students conceive mathematics directly or indirectly influences how students engage with cognitive activity in mathematics. This has been shown to influence students' learning approaches and learning outcomes that relate to their performance in mathematics (Crawford, 1992; Crawford et al., 1998b). Therefore, for reforms to be successfully executed in mathematics education, it is essential to understand how teachers (both in-service and pre-service) view mathematics so that the teaching of mathematics is not left in the hands of teachers who nurture non-availing conceptions about mathematics. In Nigeria, little research have been dedicated to pre-service mathematics teachers' conceptions of mathematics. This study assessed the factor structure and internal consistency of the CMS and paralleled the results 
with those told in Australia and other replicating studies. This study is important in that it would help in the refinement of the instrument required to measure students' conceptions of mathematics in Nigeria.

Mji and Arigbabu (2012) investigated the associations amongst the mathematics anxiety, teaching efficacy beliefs in mathematics and mathematics conceptions of 130 prospective teachers of mathematics registered in one college of education located in the Nigerian South-West geopolitical zone. Results showed that patchy formations were positively related with the two dimensions of mathematics anxiety, personal teaching efficacy in mathematics and teaching outcome expectancy in mathematics. Unified formations had positive relationship with teaching efficacy in mathematics. Outcome expectancy and teaching efficacy remained good forecasters of mathematics conceptions. However, the prospective teachers of mathematics who view mathematics as being rulesbased and formulae-dependent were more apprehensive of mathematics.

\section{Research Methods}

This study adopted the quantifiable research process in the purview of the crosssectional survey design. The respondents in this study, selected through a convenience sampling technique, were 228 undergraduate pre-service teachers enrolled in the Mathematics Education programme in 5 public universities in South-West Nigeria. These students were taken as the sample of this study because of their training in mathematics education at the university level. The sample consisted of 42 first-year students (freshmen) (18.4\%), 85 second-year students (sophomores) (37.3\%), 55 third-year students (juniors) (24.1\%), and 46 final-year students (seniors) (20.2\%). There were 133 (59.1\%) males and 85 (37.8\%) females. Ten pre-service teachers did not reveal their gender. The Crawford et al. (1998a) original 19-item Conceptions of Mathematics Scale developed and validated with an Australian sample was administered to participants and replies were documented using a 5-point scale which oscillated from 5: Strongly Agree to 1: Strongly Disagree. In a succeeding study, however, Crawford et al. (1998b) recommended an 18-item Conceptions of Mathematics Scale - having deleted the item-statement What math is about is formulae and applying to everyday life and situations that measured unified formations. The deletion was on the basis that the item on surface validity epitomized a unified conceptions while a critical analysis of the survey data, showed a high factor loading on the dimension demonstrating the patchy formations. It was therefore necessary that the psychometric properties be confirmed for use in the Nigerian context. The requisite condition was to examine whether in the South-West of Nigeria, the estimates of the internal consistency and the factor structure of the scale produced similar outcomes to those told in a different place. The authors together with five research assistants distributed the CMS to all the respondents and in their various classes in the five universities. The collected data were summarized and analyzed by mean, standard deviation, frequency count, percentage, principal components factor analysis and Cronbach alpha coefficient.

\section{Results and Discussion}

In confirming the psychometric properties of the Conceptions of Mathematics Scale, a principal component factor analysis with Varimax rotation was used. Three measures, i.e. Cattell's scree plot (1966), Horn's parallel analysis (1965), and Kaiser criterion (1960) for determining the exact number of dimensions to extract, were deployed for the scale response data on a Likert five-point scale. Only factors that met a minimum factor saliency criterion of .3 were retained. Initially, all the data collected were subjected to data 
screening processes and missing values detected were specified in the computer syntax, while screening for multivariate outliers indicated three cases (with $\mathrm{p}<0.001$ ) as multivariate outliers. These outliers were discarded as suggested by Tabachnick and Fidell (2007). Consequent scrutiny revealed no fear for linearity, normality, singularity, and multicollinearity. The association matrix exhibited for the 19 items of the CMS showed that the associations in use globally were meaningfully weighty as displayed by the Bartlett's test of sphericity, $\chi 2=1662.751 ; d f=171 ; p<.005$. This checks the trivial postulate that the association matrix is a unit matrix. A value of .885 recorded for the Kaiser-Meyer-Olkin (KMO) measure of sampling adequacy was within tolerable range (values $\geq .60$ ). This led to the conclusion that the 19-items of the Conception of Mathematics Scale was apt for PCA.

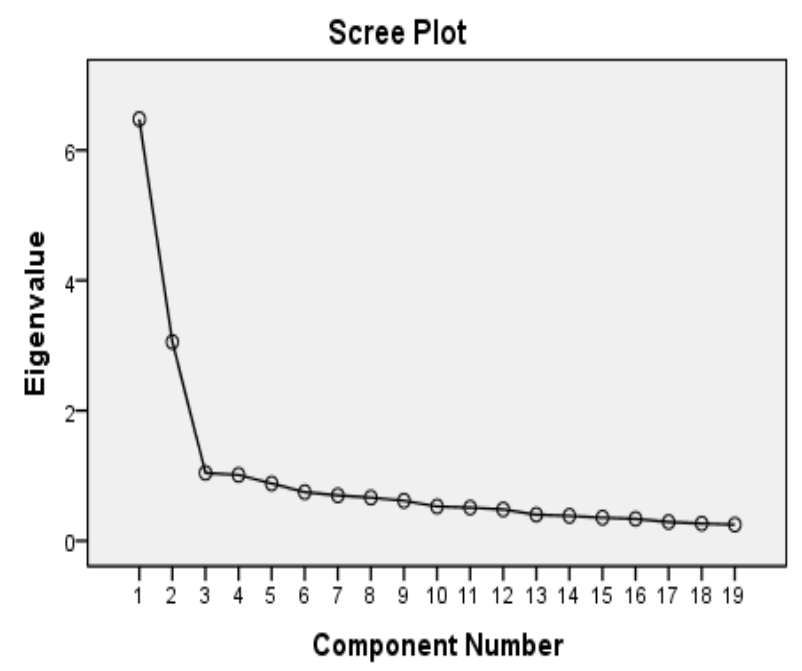

Figure 1. Cattell's scree plot showing number of components and eigenvalues of the correlation matrix

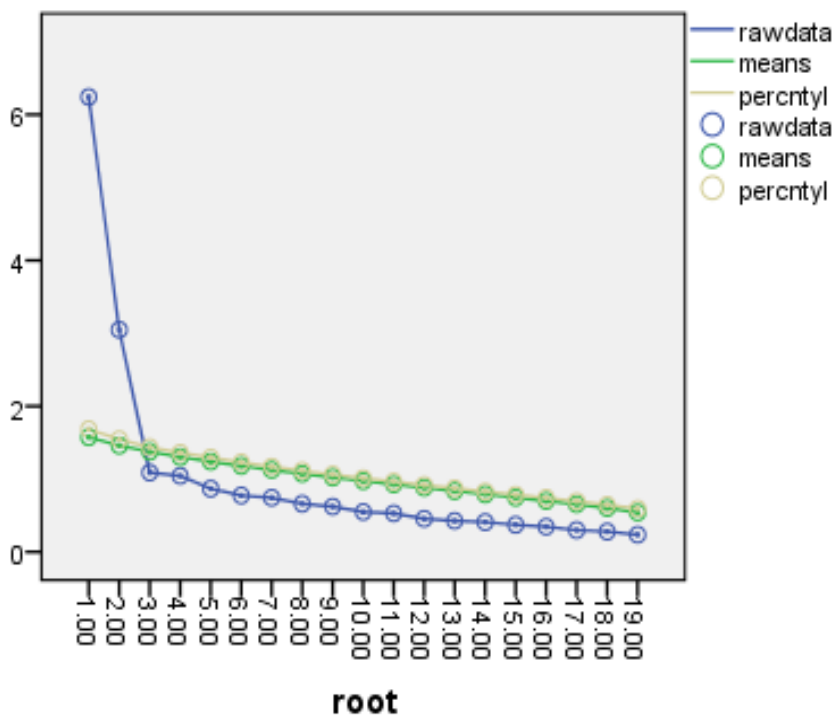

Figure 2. Parallel analysis for CMQ

Adopting the Kaiser's benchmark which stipulates a least eigenvalue $>1.00$ the study identified the primary number of dimensions to be reserved for gyration. The preliminary ungyrated PCA yielded a component model of four factors depicted by eigenvalue $>1.00$, but the scree plot which graphed the eigenvalues in order of size (interpreted by identifying the number of dimensions that appear prior to the flattening off or scree) 
suggested a two factor solution. In comparing the actual eigenvalues produced by the data to eigenvalues of a random data matrix of the same size, parallel analysis interpreted that only two factors produced an eigenvalue greater than the equivalent random data eigenvalue. However, from the configuration of component stacking, the ungyrated component model was hypothetically low evocative and was hard to explain, hence the study advanced to revolve the component matrix orthogonally by adopting varimax gyration to accomplish a modest and hypothetically high evocative result. This time SPSS was requested to generate only two factors since the default cut-off of an eigenvalue of 1 was not met with the two factor solution suggested by parallel analysis and scree plot. An assessment of the coefficients of the first two components, together with the inspection of the scree plot (shown in Figure I), and the parallel analysis (shown in Figure 2), suggested a two factor solution which explicated $48.9 \%$ of the full variance. Based on the pattern of item loading, the first component which explained $32.86 \%$ of the variance (eigenvalue= 6.24), contained ten patchy formations items; while the second component explained $16.04 \%$ of the variance (eigenvalue $=3.05$ ) and contained nine unified formations items. Hence, the two factors were construed to indicate patchy and unified formations of mathematics as extracted in the original study by Crawford et al. (1998a). However, the arrangements of factors were the same; factor 1 was patchy (fragmented) and factor 2 unified (cohesive) as indicated in earlier studies. Hair, Black, Babin, and Anderson (2014) maintained that it is common to think about a solution that accounts for $60 \%$ of the total variance or less as acceptable.

Tables 1 and 2 presented the item dimension stacking for the orthogonal two component archetypal of the conceptions of mathematics scale. The full variance explained by the two factors (48.9\%) was analogous to $41 \%$ and $50 \%$ variance established in previous study in Australia, 47\% in America and 44\% in South Africa. Nevertheless, a total of only 48.9 percent of the overall variance could imply that the questionnaire is not adequately characterized by two factors alone. The internal consistency reliabilities represented by Cronbach alpha scores showed for the present study was patchy formations $(\alpha=.88)$, and unified formations $(\alpha=.86)$. These suggest that each subscale depicts empirically independent and internally consistent mathematics conceptions construct, assessing related construct. The reliability coefficient of the entire scale $(\alpha=.88)$ measured by Cronbach alpha was taken to be very high and theoretically significant. This coefficient was similar (.79 to .88) to the one recounted in Australia (Crawford et al., 1998b), .80 in South Africa (Mji, 1999), and .89 in South-West Nigeria (Mji \& Arigbabu, 2012). Alkhateeb (2001) computed reliability coefficient of .86 for unified formations and .80 for patchy formations in the United States. All items significantly loaded .50 and above on the two components except for item 3: Math is simply an over complication of addition and subtraction on patchy formations (as appears in Tables $1 \& 2$ ) that loaded .39. The total mean and standard deviations for the 10 items of the patchy formations scale were 3.73 and 1.098 and for 9 items of the unified formations scale were 4.02 and .909. This was similar to the results obtained with the Australian students, which showed the mean and standard deviation of 3.6 and 0.3 on the unified formations scale and 3.2 and 0.6 on the patchy formations scale (Crawford et al., 1998b), in which the mean for the patchy formations scale was less than that of the unified formations scale.

However, Alkhateeb (2001) reported the mean of the patchy formations subscale (M $=3.6, \mathrm{SD}=0.5)$ to be higher than that of the unified subscale $(\mathrm{M}=3.5, \mathrm{SD}=0.2)$, among 
American students. In the present study, gender has no statistically significant influence either on the patchy formations scale $\left(\mathrm{t}_{214}=-.250, \mathrm{p}=.803\right)$ or on the unified formations scale $\left(\mathrm{t}_{212}=1.017, \mathrm{p}=.310\right)$ among Nigerian students. However, the female pre-service mathematics teachers showed a mean score $(M=36.94, S D=9.19)$ that was slightly higher than their male counterpart $(\mathrm{M}=36.67, \mathrm{SD}=6.89)$ on patchy formations; while the male pre-service mathematics teachers showed mean score $(M=36.33$, $S D=5.52)$ slightly higher than their female counterpart $(M=35.52, S D=5.91)$ on unified formations. Alkhateeb (2001) reported that American and Australian students showed similar performance in their formations of mathematics in which there was no significant mean difference on the patchy formations scale $\left(\mathrm{t}_{18}=1.92\right.$, ns) for the Australian and American students or on the unified formations scale $\left(\mathrm{t}_{14}=-1.03, \mathrm{~ns}\right)$. This supported the finding of this study in which there was no significant difference between the patchy and the unified formations among the Nigerian mathematics teacher education students.

Table 1

Pre-service mathematics teachers' Conceptions of Mathematics and summary of factor loadings by rotation matrix for the orthogonal two factor model

\begin{tabular}{|c|c|c|c|c|}
\hline \multirow{2}{*}{ No. } & & \multicolumn{2}{|c|}{ Factor Loadings } & \multirow{2}{*}{$\frac{\text { Communalities }}{\mathrm{h}^{2}}$} \\
\hline & & 1 & 2 & \\
\hline & Patchy Formations & & & \\
\hline 1. & For me math is the study of numbers & .66 & .24 & .61 \\
\hline 2. & Math is a lot of rules and equations & .55 & .26 & .52 \\
\hline 3. & $\begin{array}{l}\text { Math is simply over-complication of addition and } \\
\text { subtraction }\end{array}$ & .39 & .37 & .36 \\
\hline 4. & Math is about calculations & .74 & .09 & 68 \\
\hline 5. & $\begin{array}{l}\text { What math is about is finding answers through the use of } \\
\text { numbers and formulae }\end{array}$ & .79 & .10 & .74 \\
\hline 6. & $\begin{array}{l}\text { Math is figuring out problems involving } \\
\text { numbers }\end{array}$ & .77 & .18 & .73 \\
\hline 7. & $\begin{array}{l}\text { The subject of math deals with numbers, } \\
\text { figures and formulae }\end{array}$ & .76 & .19 & .72 \\
\hline 8. & $\begin{array}{l}\text { Math is about playing around numbers } \\
\text { and working on numerical problems }\end{array}$ & .77 & .08 & .74 \\
\hline 9. & $\begin{array}{l}\text { Math is a subject where you manipulate } \\
\text { numbers to solve problems }\end{array}$ & .61 & .27 & .59 \\
\hline 10. & $\begin{array}{l}\text { Math is the study of the number } \\
\text { system and solving numerical problems } \\
\text { Unified Formations }\end{array}$ & .72 & .29 & .69 \\
\hline 11. & By using math we can generate new knowledge & .24 & .69 & .66 \\
\hline 12. & $\begin{array}{l}\text { Math is a set of logical systems which have been } \\
\text { developed to explain the worldand the relationships in it }\end{array}$ & .29 & .75 & .73 \\
\hline 13. & $\begin{array}{l}\text { I think math provides an insight into the complexities of } \\
\text { our realities }\end{array}$ & .22 & .71 & .68 \\
\hline 14. & $\begin{array}{l}\text { Math is theoretical framework describing reality with the } \\
\text { aim of helping us understand the world }\end{array}$ & .09 & .72 & .69 \\
\hline 15. & $\begin{array}{l}\text { Math uses logical structures to solve and explain real life } \\
\text { problems }\end{array}$ & .27 & .69 & .66 \\
\hline 16. & $\begin{array}{l}\text { Math is like a universal language whichallows people } \\
\text { communicate and understand the universe }\end{array}$ & .28 & .62 & .58 \\
\hline 17. & $\begin{array}{l}\text { What math is about is formulae and applying them to } \\
\text { everyday life and situations }\end{array}$ & .24 & .54 & .51 \\
\hline 18. & $\begin{array}{l}\text { Math is a logical system which helps explain the things } \\
\text { around us }\end{array}$ & .26 & .77 & .74 \\
\hline 19. & $\begin{array}{l}\text { Math is a model which have been devised over years to } \\
\text { help us explain, answer and } \\
\text { investigate matters in the world }\end{array}$ & .28 & .59 & .56 \\
\hline
\end{tabular}


Table 2

Pre-service mathematics teachers' Conceptions of Mathematics and summary of factor loadings by Principal Component analysis for the orthogonal two factor model

\begin{tabular}{|c|c|c|c|c|c|c|c|c|c|}
\hline & \multicolumn{5}{|c|}{$\mathrm{N}(\%)$} & \multirow{2}{*}{ Mean } & \multirow{2}{*}{ Std. } & \multirow{2}{*}{$\begin{array}{l}\text { F.Loa } \\
\text { dgs }\end{array}$} \\
\hline & & SD & D & $\mathbf{N}$ & AS & $\mathbf{A}$ & & & \\
\hline \multicolumn{10}{|c|}{ Patchy Formations } \\
\hline 1. & $\begin{array}{l}\text { For me math is the } \\
\text { study of numbers }\end{array}$ & $\begin{array}{c}33 \\
(14.7)\end{array}$ & $\begin{array}{c}43 \\
(19.1)\end{array}$ & $\begin{array}{c}32 \\
(14.2)\end{array}$ & $\begin{array}{c}85 \\
(37.8)\end{array}$ & $\begin{array}{c}28 \\
(12.4)\end{array}$ & 3.14 & 1.292 & .66 \\
\hline & $\begin{array}{l}\text { Math is a lot of rules } \\
\text { and equations }\end{array}$ & $\begin{array}{c}4 \\
(1.8)\end{array}$ & $\begin{array}{c}18 \\
(8.0)\end{array}$ & $\begin{array}{c}28 \\
(12.4)\end{array}$ & $\begin{array}{c}109 \\
(48.4)\end{array}$ & $\begin{array}{c}64 \\
(28.4)\end{array}$ & 3.95 & .948 & .55 \\
\hline 3. & $\begin{array}{l}\text { Math is simply over- } \\
\text { complication of } \\
\text { addition and } \\
\text { subtraction }\end{array}$ & $\begin{array}{c}16 \\
(7.1)\end{array}$ & $\begin{array}{c}49 \\
(21.8)\end{array}$ & $\begin{array}{c}46 \\
(20.4)\end{array}$ & $\begin{array}{c}75 \\
(33.3)\end{array}$ & $\begin{array}{c}36 \\
(16.0)\end{array}$ & 3.30 & 1.189 & .39 \\
\hline & $\begin{array}{l}\text { Math is about } \\
\text { calculations }\end{array}$ & $\begin{array}{c}13 \\
(5.8)\end{array}$ & $\begin{array}{c}25 \\
(11.1)\end{array}$ & $\begin{array}{c}23 \\
(10.2)\end{array}$ & $\begin{array}{c}89 \\
(39.6)\end{array}$ & $\begin{array}{c}71 \\
(31.6)\end{array}$ & 3.81 & 1.174 & .74 \\
\hline 5. & $\begin{array}{l}\text { What math is about } \\
\text { is finding answers } \\
\text { through the use of } \\
\text { numbers and } \\
\text { formulae }\end{array}$ & $\begin{array}{c}5 \\
(2.2)\end{array}$ & $\begin{array}{c}32 \\
(14.2)\end{array}$ & $\begin{array}{c}22 \\
(9.8)\end{array}$ & $\begin{array}{c}93 \\
(41.3)\end{array}$ & $\begin{array}{c}70 \\
(31.1)\end{array}$ & 3.86 & 1.086 & .79 \\
\hline 6. & $\begin{array}{l}\text { Math is figuring out } \\
\text { problems involving } \\
\text { numbers }\end{array}$ & $\begin{array}{c}6 \\
(2.7)\end{array}$ & $\begin{array}{c}33 \\
(14.7)\end{array}$ & $\begin{array}{c}25 \\
(11.1)\end{array}$ & $\begin{array}{c}101 \\
(44.9)\end{array}$ & $\begin{array}{c}55 \\
(24.4)\end{array}$ & 3.75 & 1.074 & .77 \\
\hline & $\begin{array}{l}\text { The subject of math } \\
\text { deals with numbers, } \\
\text { figures and } \\
\text { formulae }\end{array}$ & $\begin{array}{c}3 \\
(1.3)\end{array}$ & $\begin{array}{c}21 \\
(9.3)\end{array}$ & $\begin{array}{c}23 \\
(10.2)\end{array}$ & $\begin{array}{c}97 \\
(43.1)\end{array}$ & $\begin{array}{c}76 \\
(33.8)\end{array}$ & 4.01 & .979 & .76 \\
\hline & $\begin{array}{l}\text { Math is about } \\
\text { playing around } \\
\text { numbers and } \\
\text { working on } \\
\text { numerical problems }\end{array}$ & $\begin{array}{c}9 \\
(4.0)\end{array}$ & $\begin{array}{c}26 \\
(11.6)\end{array}$ & $\begin{array}{c}31 \\
(13.8)\end{array}$ & $\begin{array}{c}96 \\
(42.7)\end{array}$ & $\begin{array}{c}60 \\
(29.7)\end{array}$ & 3.77 & 1.094 & .77 \\
\hline & $\begin{array}{l}\text { Math is a subject } \\
\text { where you } \\
\text { manipulate } \\
\text { numbers to solve } \\
\text { problems }\end{array}$ & $\begin{array}{c}9 \\
(4.0)\end{array}$ & $\begin{array}{c}27 \\
(12.0)\end{array}$ & $\begin{array}{c}35 \\
(15.6)\end{array}$ & $\begin{array}{c}95 \\
(42.2)\end{array}$ & $\begin{array}{c}55 \\
(24.4)\end{array}$ & 3.72 & 1.092 & .61 \\
\hline & $\begin{array}{l}\text { Math is the study of } \\
\text { the number system } \\
\text { and solving } \\
\text { numerical problems }\end{array}$ & $\begin{array}{c}8 \\
(3.6)\end{array}$ & $\begin{array}{c}18 \\
(8.0)\end{array}$ & $\begin{array}{c}24 \\
(10.7)\end{array}$ & $\begin{array}{c}97 \\
(43.1)\end{array}$ & $\begin{array}{c}73 \\
(32.4)\end{array}$ & 3.95 & 1.048 & .72 \\
\hline $\begin{array}{l}\text { Sub- } \\
\text { Unifi }\end{array}$ & $\begin{array}{l}\text { otal } \\
\text { d Formations }\end{array}$ & & & & & & 3.73 & 1.098 & \\
\hline & $\begin{array}{l}\text { By using math we } \\
\text { can generate new } \\
\text { knowledge }\end{array}$ & $\begin{array}{c}7 \\
(3.1)\end{array}$ & $\begin{array}{c}12 \\
(5.3)\end{array}$ & $\begin{array}{c}22 \\
(9.8)\end{array}$ & $\begin{array}{c}101 \\
(44.9)\end{array}$ & $\begin{array}{c}79 \\
(35.1)\end{array}$ & 4.05 & .980 & .69 \\
\hline & $\begin{array}{l}\text { Math is a set of } \\
\text { logical systems } \\
\text { which have been } \\
\text { developed to explain } \\
\text { the world and the } \\
\text { relationships in it }\end{array}$ & $\begin{array}{c}2 \\
(0.9)\end{array}$ & $\begin{array}{c}10 \\
(4.4)\end{array}$ & $\begin{array}{c}30 \\
(13.3)\end{array}$ & $\begin{array}{c}107 \\
(47.6)\end{array}$ & $\begin{array}{c}72 \\
(32.0)\end{array}$ & 4.07 & .850 & .75 \\
\hline & $\begin{array}{l}\text { I think math } \\
\text { provides an insight } \\
\text { into the } \\
\text { complexities of our } \\
\text { realities }\end{array}$ & $\begin{array}{c}5 \\
(2.2)\end{array}$ & $\begin{array}{c}7 \\
(3.1)\end{array}$ & $\begin{array}{c}27 \\
(12.0)\end{array}$ & $\begin{array}{c}112 \\
(49.8)\end{array}$ & $\begin{array}{c}70 \\
(31.1)\end{array}$ & 4.06 & .877 & .71 \\
\hline
\end{tabular}


Table 2

Pre-service mathematics teachers' Conceptions of Mathematics and summary of factor loadings by Principal Component analysis for the orthogonal two factor model

\begin{tabular}{|c|c|c|c|c|c|c|c|c|c|}
\hline & \multicolumn{5}{|c|}{$\mathrm{N}(\%)$} & \multirow{2}{*}{ Mean } & \multirow{2}{*}{ Std. } & \multirow{2}{*}{$\begin{array}{c}\text { F.Loa } \\
\text { dgs }\end{array}$} \\
\hline & & SD & D & $\mathrm{N}$ & AS & $\mathbf{A}$ & & & \\
\hline 14. & $\begin{array}{l}\text { Math is theoretical } \\
\text { framework } \\
\text { describing } \\
\text { reality with the aim } \\
\text { of helping us } \\
\text { understand the } \\
\text { world }\end{array}$ & $\begin{array}{c}10 \\
(4.4)\end{array}$ & $\begin{array}{c}5 \\
(2.2)\end{array}$ & $\begin{array}{c}38 \\
(16.9)\end{array}$ & $\begin{array}{c}102 \\
(45.3)\end{array}$ & $\begin{array}{c}64 \\
(28.4)\end{array}$ & 3.94 & .984 & .72 \\
\hline 15. & $\begin{array}{l}\text { Math uses logical } \\
\text { structures to solve } \\
\text { and explain real life } \\
\text { problems }\end{array}$ & $\begin{array}{c}2 \\
(0.9)\end{array}$ & $\begin{array}{c}8 \\
(3.6)\end{array}$ & $\begin{array}{c}24 \\
(10.7)\end{array}$ & $\begin{array}{c}115 \\
(51.1)\end{array}$ & $\begin{array}{c}72 \\
(32.0)\end{array}$ & 4.12 & .806 & .69 \\
\hline 16. & $\begin{array}{l}\text { Math is like a } \\
\text { universal language } \\
\text { which } \\
\text { allows people } \\
\text { communicate and } \\
\text { understand } \\
\text { the universe }\end{array}$ & $\begin{array}{c}6 \\
(2.7)\end{array}$ & $\begin{array}{c}22 \\
(9.8)\end{array}$ & $\begin{array}{c}35 \\
(15.9)\end{array}$ & $\begin{array}{c}91 \\
(40.4)\end{array}$ & $\begin{array}{c}67 \\
(29.8)\end{array}$ & 3.86 & 1.044 & .62 \\
\hline 17. & $\begin{array}{l}\text { What math is about } \\
\text { is formulae and } \\
\text { applyingthem to } \\
\text { everyday life and } \\
\text { situations }\end{array}$ & $5(2.2)$ & $\begin{array}{c}17(7.6 \\
)\end{array}$ & $28(12.4)$ & $\begin{array}{c}111(49 . \\
3)\end{array}$ & $60(26.7)$ & 3.92 & .953 & .54 \\
\hline 18. & $\begin{array}{l}\text { Math is a logical } \\
\text { system which helps } \\
\text { explain } \\
\text { the things around us }\end{array}$ & $\begin{array}{c}3 \\
(1.3)\end{array}$ & $\begin{array}{c}12 \\
(5.3)\end{array}$ & $\begin{array}{c}35 \\
(15.6)\end{array}$ & $\begin{array}{c}104 \\
(40.2)\end{array}$ & $\begin{array}{c}66 \\
(29.3)\end{array}$ & 3.99 & .896 & .77 \\
\hline 19. & $\begin{array}{l}\text { Math is a model } \\
\text { which havebeen } \\
\text { devised } \\
\text { over years to help } \\
\text { us explain, answer } \\
\text { and } \\
\text { investigate matters } \\
\text { in the world }\end{array}$ & $\begin{array}{c}2 \\
(0.9)\end{array}$ & $\begin{array}{c}4 \\
(1.8)\end{array}$ & $\begin{array}{c}31 \\
(13.8)\end{array}$ & $\begin{array}{c}108 \\
(48.0)\end{array}$ & $\begin{array}{c}76 \\
(33.4)\end{array}$ & 4.14 & .788 & .59 \\
\hline \multirow{2}{*}{\multicolumn{2}{|c|}{$\begin{array}{l}\text { Sub-total } \\
\text { Total }\end{array}$}} & & & & & & 4.02 & .909 & \\
\hline & & & & & & & 3.88 & 1.004 & \\
\hline
\end{tabular}

It is a common knowledge that students may espouse either the patchy formation or unified formation of mathematics based on their perception of the learning environment. Impacts from the students' viewpoint may be clothed in anxiety arising from the dread of failure and poor attitude attitudes towards mathematics (Awofala, 2016). The dread of disappointment may make students to restrict their learning to only the syllabus and so rely on rote learning instead of engaging in thorough conceptual understanding of facts. More so, effects from the pedagogical milieu such as continuous assessment practices in form of quizzes and examinations that facilitate the regurgitation of specifics can promote "learners' adoption of patchy formations. Students with patchy formations adopt surface approach to learning of mathematics. Thus, these influences from the pedagogical context can be controlled by making students to keep and retain journals and journal keeping may allow students to mirror their frame of mind and philosophies about mathematics. 
Students with unified formations tend not only to use deep approach to learning of mathematics but adopt constructivist principles in the learning of mathematics. In addition, they engage in conceptual understanding which leads them to procedural fluency, to the ultimate aim of seeing sense in mathematics and perceive that mathematics is useful and worthwhile and that perseverance in mathematics pays off. Thus, students with unified formations tend to have high productive dispositions and are capable of engaging in logical thought about mathematics thereby giving room for adaptive reasoning. The pedagogy adopted during the teaching and learning of mathematics can affect students' conceptions of mathematics (Carstensen, degaard, \& Bonsaksen, 2018; Monroy \& González-Geraldo, 2018). In essence, when mathematics is taught with teacher-centered pedagogy, students would see mathematics as consisting of rules and algorithms that must be mastered through rote memorization thereby developing patchy formations. However, when mathematics is taught with student-centered pedagogies such as cooperative learning, personalization of instruction and problem-based learning, students would view mathematics as a meaningful subject full of applications to the real life which may result to unified formations. In essence, there is a stable configuration of relationships between using deep approaches and attaining good academic performance whereas surface approaches have been connected with worse academic performance (Bonsaksen, Brown, Lim, \& Fong, 2017; Bonsaksen, 2018; Alt \& Boniel-Nissim, 2018).

\section{Conclusion}

The present study results albeit showed that the responses of the Nigerian mathematics education students produced a stable component structure similar to Crawford et al. (1998a). Based on this similar factor structure, it is understood that the conceptions of mathematics scale has sound psychometric properties. In addition, the CMS is an internally consistent and valid measure of Nigerian undergraduate mathematics education students' conceptions of mathematics. It is noted that students may adopt patchy or unified formations of mathematics because of the awareness they develop from the educational milieu. The implication of this study is that students with patchy formation are connected with surface approaches to learning while those with unified formation of mathematics are connected with deep approaches to learning and engaging mathematics. In conclusion, it is recommended that investigation of this scale across other cultural contexts within Nigeria is essential to judge its general suitability.

\section{Acknowledgment}

The authors would like to recognize the backing of the pre-service mathematics teachers that willingly took part in the study. Thank you for your unalloyed support.

\section{Bibliography}

Akinsola, M. K., \& Awofala, A. O. A. (2008). Effects of problem context and reasoning complexity on mathematics problem solving achievement and transfer of secondary school students. European Journal of Scientific Research, 20(3), 641-651.

Alkhateeb, H. M. (2001). University students' conceptions of first-year mathematics. Psychological Reports, 89, 41- 47. https://doi.org/10.2466/pr0.2001.89.1.41.

Alt, D. \& Boniel-Nissim, M. (2018). Links between Adolescents' Deep and Surface Learning Approaches, Problematic Internet Use, and Fear of Missing Out (FoM0). Internet Interventions, 13, 30-39. https://doi.org/10.1016/i.invent.2018.05.002 
Awofala, A. 0. A. (2011). Effect of personalized, computer-based instruction on students' achievement in solving two-step word problems. International Journal of Mathematics Trends and Technology. 2(2), 5-10.http://www.ijmttjournal.org/Volume-2/issue2/IJMTT-V2I2P502.pdf

Awofala, A. 0. A. (2012). An analysis of the new 9-year basic education mathematics curriculum in Nigeria in the new millennium. Acta Didactica Napocensia, 5(1), 156170. https://eric.ed.gov/?id=EJ1054294

Awofala, A. 0. A. (2016). Examining preservice mathematics teachers' attitudes toward mathematics. Nigerian Journal of Curriculum Studies, 23, 292-300.

Awofala, A. O. A. \& Awolola, S. A. (2011).Curriculum value orientation and reform in the 9year basic education mathematics curriculum. In O.S. Abonyi (Ed.) Proceedings of $52^{\text {nd }}$ Annual Conference of the Science Teachers Association of Nigeria on Reforms in Science, Technology, Engineering and Mathematics ( pp.297-303). HEBN Publishers Plc.

Awofala, A. O. A, Ola-Oluwa, S. A. \& Fatade, A. 0. (2012). Teachers' perception of the new nine-year basic education mathematics curriculum in Nigeria. International Journal of Mathematics Trends and Technology, 3(1), 1-6. http://www.ijmttjournal.org/Volume3/issue-1/IJMTT-V3I1P501.pdf

Bonsaksen, T., Brown, T., Lim, H. B. \& Fong, K. (2017). Approaches to studying predict academic performance in undergraduate occupational therapy students: a crosscultural study. BMC Medical Education, 17(1), 76. https://doi.org/10.1186/s12909017-0914-3

Bonsaksen, T. (2018). Deep, surface, or both? A study of occupational therapy students' learning concepts. Occupational Therapy International, 1-8. https://doi.org/10.1155/2018/3439815

Carstensen, T., Ødegaard, N. B. \&Bonsaksen, T. (2018). Approaches to studying: associations with learning conceptions and preferences for teaching. Cogent Education, 5(1), 1-11. https://doi.org/10.1080/2331186X.2018.1480909

Cattell, R. B. (1966). The scree test for the number of factors. Multivariate Behavioral Research, 1, 245-276.https://doi.org/10.1207/s15327906mbr0102 10

Crawford, K. (1992). Cultural processes and learning: exectations, actions and outcomes [paper presentation]. The International Congress on Mathematics Education, Quebec, City, Canada, August.

Crawford, K., Gordon, S., Nicholas, J., \& Prosser, M. (1994). Conceptions of mathematics and how it is learned: the perspectives of students entering university. Learning and Instruction, 4 , 331 -345. https://doi.org/10.1016/0959-4752(94)90005-1

Crawford, K., Gordon, S., Nicholas, J., \& Prosser, M. (1998a). Qualitatively different experiences of learning mathematics at university. Learning and Instruction, 8, 455 468. https://doi.org/10.1016/S0959-4752(98)00005-X

Crawford, K., Gordon, S., Nicholas, J., \& Prosser, M. (1998b). University mathematics students' conceptions of mathematics. Studies in Higher Education, 23, 87 - 94. https://doi.org/10.1080/03075079812331380512

Erdem, E., \& Gürbüz, R. (2015). An analysis of seventh-grade students' mathematical reasoning. Cukurova University Faculty of Education Journal, 45(1), 123-142. https://dergipark.org.tr/en/pub/cuefd/issue/4139/54361

Hair Jr., J. F., Black, W. C., Babin, . J. \& Anderson, R. E. (2009). Multivariate data analysis. Seventh Edition. Pearson Education Limited.

Horn, J. L. (1965). A rationale and test for the number of factors in factor analysis. Psychometrika, 30, 179-185. https://doi.org/10.1007/BF02289447 
Kaiser, H. F. (1960). The application of electronic computers to factor analysis. Educational $\begin{array}{lllll}\text { and Psychological } & \text { Measurement, } & \text { 20(1), } & 141 & -\end{array}$ https://doi.org/10.1177\%2F001316446002000116

Mji, A. (1999). Reliability and validity of the conceptions of mathematics questionnaire. Psychological Reports, $85(2)$, 579

582. https://doi.org/10.2466\%2Fpr0.1999.85.2.579

Mji, A., \& Arigbabu, A. A. (2012). Relationship between and among preservice mathematics teachers' conceptions, efficacy beliefs and anxiety. International Journal of Education Science, 4(3), 261 - 270. https://doi.org/10.1080/09751122.2012.11890051

Monroy, F. \& González-Geraldo, J. L. (2018). Measuring learning: discrepancies between conceptions of and approaches to learning. Educational Studies, 44(1), 81-98.

Nigerian Educational and Research and Development Council. (NERDC, 2013). 9-year Basic Education Curriculum, Mathematics for Upper Basic Education. Lagos: NERDC Press. http://www.nerdc.org.ng/eCurriculum/CurriculumStructure.aspx.

Tabachnick, B. G. \& Fidell, L. S. (2007). Using multivariate statistics (5th Ed.). Boston, MA, Allyn \& Bacon. 